\title{
Siphonobacter aquaeclarae gen. nov., sp. nov., a novel member of the family 'Flexibacteraceae', phylum Bacteroidetes
}

Correspondence

András Táncsics

tancsics@elte.hu

\author{
András Táncsics, ${ }^{1}$ Zsuzsa Kéki, ${ }^{1}$ Károly Márialigeti, ${ }^{1}$ Peter Schumann ${ }^{2}$ \\ and Erika M. Tóth ${ }^{1}$ \\ ${ }^{1}$ Department of Microbiology, Eötvös Loránd University, H-1117 Budapest, Pázmány P. stny. 1/C, \\ Hungary
${ }^{2}$ DSMZ - German Collection of Microorganisms and Cell Cultures, Inhoffenstrasse 7B, D-38124 Braunschweig, Germany

\begin{abstract}
A Gram-negative bacterium, designated $\mathrm{P} 2^{\top}$, was isolated from the biofilm developed on the inner surface of an ultrapure cooling water system in a Hungarian power plant and was characterized by a polyphasic approach. Phylogenetic analysis based on 16S rRNA gene sequences revealed that strain $\mathrm{P} 2{ }^{\top}$ was affiliated with the family 'Flexibacteraceae' in the phylum Bacteroidetes. Its closest relative was Flectobacillus lacus CL-GP79 ${ }^{\top}$ (88.7\% 16S rRNA gene sequence similarity) followed by Arcicella rosea TW5 ${ }^{\top}$ (86.5\%), Arcicella aquatica NO-502 ${ }^{\top}$ (86.4 \%), Flectobacillus roseus GFA $11^{\top}(86.3 \%)$ and Flectobacillus major DSM $103^{\top}(85.4 \%)$. Cells of strain $\mathrm{P}^{\top}{ }^{\top}$ were facultatively anaerobic, non-motile rods. The major fatty acids were $\mathrm{C}_{16: 1} \omega 5 c(42.5 \%)$, iso- $\mathrm{C}_{15: 0}$ $2-\mathrm{OH}(17.2 \%)$, iso- $\mathrm{C}_{17: 0} 3-\mathrm{OH}(16.1 \%)$ and iso- $\mathrm{C}_{15: 0}(8.5 \%)$. The major menaquinone was MK-7 and the predominant polar lipid was phosphatidylethanolamine. The DNA G+C content was 54.5 mol\%. Thus, the phenotypic and genotypic analyses clearly showed that strain $\mathrm{P} 2^{\top}$ is considerably different from members of other genera in the family 'Flexibacteraceae'. Based on these results, it is concluded that strain $\mathrm{P} 2^{\top}$ represents a novel species in a new genus, for which the name Siphonobacter aquaeclarae gen. nov., sp. nov. is proposed, with type strain $\mathrm{P} 2^{\top}$ (=DSM $21668^{\top}=$ NCAIM B $02328^{\top}$ ).
\end{abstract}

Bacteria that are affiliated with the phylum Bacteroidetes are widely distributed in nature, especially in aquatic ecosystems (Kirchman, 2002; Zwart et al., 2002), and they play a significant role in biogeochemical cycling and in the degradation of complex biopolymers (Cottrell \& Kirchman, 2000). Some of them take part in freshwater biofilm formation, like species of the genera Adhaeribacter (Rickard et al., 2005) and Arcicella (Furuhata et al., 2008). Biofilm formation in industrial water systems (e.g. in cooling water systems) is an undesirable process because it can result in microbially induced corrosion of pipe surfaces or obturation of the pipes (Branda et al., 2005). Therefore, the investigation of formation and microbial composition of freshwater biofilms has been in focus and novel species have been isolated from a highly eutrophic pond (Flectobacillus lacus; Hwang \& Cho, 2006), freshwater (Flectobacillus major and F. roseus; Gromov, 1963; Sheu et al., 2009), a freshwater neuston film (Arcicella aquatica; Nikitin et al., 2004) and tap water (Arcicella rosea TW5 ${ }^{\mathrm{T}}$; Kämpfer et al., 2009). A novel bacterium, strain $\mathrm{P} 2^{\mathrm{T}}$, was isolated from a biofilm sample

The GenBank/EMBL/DDBJ accession number for the 16S rRNA gene sequence of strain $\mathrm{P}^{\top}{ }^{\top}$ is FJ177421. obtained from the inner surface of an ultrapure cooling water pipeline. Based on the $16 \mathrm{~S}$ rRNA gene sequence, the isolate was affiliated with the family 'Flexibacteraceae' but showed a considerably low level of sequence similarity with strains of previously described species of this family.

A biofilm sample was taken from the inner surface of a cooling water system in a Hungarian power plant. The sampled pipeline system contained ultrapure, desalinated water, of which the temperature varied between 23 and $25{ }^{\circ} \mathrm{C}$. The sample was serially diluted in physiological saline $(0.9 \%, \mathrm{w} / \mathrm{v}, \mathrm{NaCl})$, plated on $\mathrm{R} 2 \mathrm{~A}$ agar (medium 830, DSMZ) and incubated at $28{ }^{\circ} \mathrm{C}$ for 1 week under aerobic conditions. Colonies were selected randomly and purified twice on R2A agar at $28{ }^{\circ} \mathrm{C}$. Growth was tested on R2A agar, nutrient agar (medium 1, DSMZ), tryptic soy agar (TSA; Difco) and on MacConkey agar (Difco).

Colony morphology of strain $\mathrm{P} 2^{\mathrm{T}}$ was tested on $\mathrm{R} 2 \mathrm{~A}$ agar by direct observation of single colonies. Cell morphology and motility were studied by native preparation and by Gramstaining according to Claus (1992). Growth in the absence of oxygen was tested using R2A agar slants incubated in an anaerobic chamber (Forma Scientific). Oxidase activity was 
studied by the method of Tarrand \& Gröschel (1982). Catalase production and Voges-Proskauer reaction were demonstrated by the methods of Cowan \& Steel (1974). Acid production from D-glucose was checked by the OF test according to Hugh \& Leifson (1953). Growth at $4-60{ }^{\circ} \mathrm{C}$ was determined using R2A agar. Tolerance to $0,2.5,5$ and $10 \%$, $\mathrm{w} / \mathrm{v}, \mathrm{NaCl}$ and $\mathrm{pH} 3-11$ (in increments of one $\mathrm{pH}$ unit) were determined using R2A broth. Urease activity, reduction of $\mathrm{NO}_{3}{ }^{-}$, starch hydrolysis, caseinase, gelatinase, phosphatase activity and hydrolysis of Tween 80 were studied according to Smibert \& Krieg (1994). Acid production from different carbon sources and enzymic activities of strain $\mathrm{P} 2^{\mathrm{T}}$ were investigated with API $50 \mathrm{CH}$ and API ZYM kits (bioMérieux) at $28{ }^{\circ} \mathrm{C}$, according to the manufacturer's instructions. The API ZYM tests were read after $4 \mathrm{~h}$ and the API $50 \mathrm{CH}$ tests were read after $24-48 \mathrm{~h}$.

For isoprenoid quinone analysis, cells were cultivated in liquid Rich medium (Yamada \& Komagata, 1972). Quinones were extracted according to the method of Collins et al. (1977) and the profile was analysed by HPLC (HP
9001; Groth et al., 1997). For polar lipid and fatty acid analysis, cells were cultivated in R2A broth and TSA, respectively, for $24 \mathrm{~h}$. Cellular fatty acids were extracted by the method of Stead et al. (1992) and analysed by GC (Groth et al., 1996). Summed features were analysed later by mass spectrometry. Polar lipids were determined according to the method described by Minnikin et al. (1979).

The DNA base composition was determined from bacterial cells disrupted by using a French press. After purification of the DNA on hydroxyapatite according to the procedure of Cashion et al. (1977), DNA was degraded to nucleosides using P1 nuclease and bovine intestinal mucosa alkaline phosphatase, as described by Mesbah et al. (1989). The nucleosides were separated by reversed-phase HPLC, as described by Tamaoka \& Komagata (1984). The G+C content of the DNA was calculated from the ratio of deoxyguanosine to thymidine.

To perform PCR amplification of the 16S rRNA gene, genomic DNA was isolated using the G-spin Genomic DNA

Table 1. Phenotypic characteristics differentiating strain $P 2^{\top}$ from related taxa

Strains: 1, Siphonobacter aquaeclarae sp. nov. P2 ${ }^{\mathrm{T}}$; 2, Flectobacillus lacus CL-GP79 ${ }^{\mathrm{T}}$ (Hwang \& Cho, 2006); 3, F. major DSM 103 ${ }^{\mathrm{T}}$ (Hwang \& Cho, 2006); 4, F. roseus GFA- $11^{\mathrm{T}}$ (Sheu et al., 2009); 5, Arcicella aquatica NO-502 ${ }^{\mathrm{T}}$ (Nikitin et al., 2004); 6, A. rosea TW5 ${ }^{\mathrm{T}}$ (Kämpfer et al., 2009). +, Positive; $v$, variable; $\mathrm{W}$, weakly positive; - , negative; ND, no data available.

\begin{tabular}{|c|c|c|c|c|c|c|}
\hline Characteristic & 1 & 2 & 3 & 4 & 5 & 6 \\
\hline \multicolumn{7}{|l|}{ Cell dimensions $(\mu \mathrm{m})$} \\
\hline Length & $1.3-2.7$ & $4.7-10.0$ & $2.0-5.0$ & $1.5-2.5$ & $2.5-3.0$ & $\mathrm{ND}$ \\
\hline Width & $0.3-0.4$ & $0.3-0.6$ & $0.6-1.0$ & $0.3-0.5$ & $0.5-0.75$ & $\mathrm{ND}$ \\
\hline \multicolumn{7}{|l|}{ Temperature for growth $\left({ }^{\circ} \mathrm{C}\right)$} \\
\hline Range & $4-37$ & $10-35$ & $4-30$ & $10-40$ & $4-40$ & $15-36$ \\
\hline Optimum & $20-30$ & $25-30$ & $20-30$ & 30 & $28-30$ & ND \\
\hline \multicolumn{7}{|l|}{$\mathrm{pH}$ for growth } \\
\hline Range & $5-9$ & $6-9$ & $6-8$ & $7-8$ & ND & ND \\
\hline Optimum & 7 & 7 & 7 & 7 & 7 & $\mathrm{ND}$ \\
\hline \multicolumn{7}{|l|}{ Biochemical tests } \\
\hline Catalase & + & + & $\mathrm{w}$ & + & + & ND \\
\hline Gelatinase & + & + & + & ND & ND & $\mathrm{ND}$ \\
\hline Oxidase & - & + & + & + & ND & - \\
\hline Nitrate reductase & - & $\mathrm{V}$ & - & - & - & $\mathrm{ND}$ \\
\hline Urease & - & - & $\mathrm{V}$ & - & - & $\mathrm{ND}$ \\
\hline Voges-Proskauer test & - & - & - & ND & $\mathrm{ND}$ & $\mathrm{ND}$ \\
\hline Glucose fermentation & - & + & + & - & - & $\mathrm{ND}$ \\
\hline Indole production & - & - & + & - & $\mathrm{ND}$ & $\mathrm{ND}$ \\
\hline \multicolumn{7}{|l|}{ Acid production from: } \\
\hline L-Arabinose & - & - & + & $\mathrm{v}$ & + & - \\
\hline L-Fucose & + & - & + & $\mathrm{v}$ & $\mathrm{ND}$ & ND \\
\hline D-Lyxose & + & - & + & - & ND & $\mathrm{ND}$ \\
\hline D-Mannose & + & - & + & + & $\mathrm{ND}$ & - \\
\hline D-Tagatose & + & - & - & - & ND & $\mathrm{ND}$ \\
\hline D-Arabitol & - & + & - & - & $\mathrm{ND}$ & ND \\
\hline D-Mannitol & - & - & - & - & + & - \\
\hline Amygdalin & + & - & + & $\mathrm{V}$ & ND & ND \\
\hline Arbutin & + & - & + & + & ND & - \\
\hline DNA G $+C$ content $(\mathrm{mol} \%)$ & 54.5 & 38.3 & 39.5 & 39.7 & 34.5 & $\mathrm{ND}$ \\
\hline
\end{tabular}


Extraction kit (iNtRON Biotechnology). Amplification was performed using the primers 27F and 1492R (Lane, 1991). PCR products were purified with the PCRquick-spin PCR Purification kit (iNtRON Biotechnology). The almostcomplete 16S rRNA gene sequence of the strain was determined by using the BigDye Terminator v3.1 Cycle Sequencing kit (Applied Biosystems), according to the manufacturer's instructions. Sequencing products were separated on a model 3100 Genetic Analyzer (Applied Biosystems). The sequences were aligned with MEGA4 software (Tamura et al., 2007) against sequences from the GenBank database (Altschul et al., 1997). A phylogenetic tree was reconstructed using the neighbour-joining method (Saitou \& Nei, 1987) and bootstrap analysis for 1000 replications was also conducted.

Strain $\mathrm{P} 2^{\mathrm{T}}$ grew well on R2A agar, nutrient agar and TSA but no growth was observed on MacConkey agar. Colonies were initially mucoid and light yellow but became light brown after 1 week of incubation. Cells were Gram-stain-negative, facultatively anaerobic, straight, non-motile rods. Good growth was observed between 4 and $37^{\circ} \mathrm{C}$ (optimum 20 $30{ }^{\circ} \mathrm{C}$ ). No growth was detected on R2A agar supplemented with $2.5-10 \%(\mathrm{w} / \mathrm{v}) \mathrm{NaCl}$. Growth was observed at $\mathrm{pH} 5-9$ (optimum $\mathrm{pH} 7$ ). With the API ZYM tests, strain $\mathrm{P}^{\mathrm{T}}$ showed high activities of amino acid-hydrolysing enzymes. More detailed characteristics are given in Table 1 and the species description.

Some results of the chemotaxonomic analysis of strain $\mathrm{P}^{\mathrm{T}}$ were similar to those of its closest relatives. The major isoprenoid quinone of strain $\mathrm{P}^{\mathrm{T}}$ was MK-7 and a trace amount of MK-5 was also observed. Investigation of the polar lipid profile showed that the main component was phosphatidylethanolamine. At the same time, the fatty acid profile of strain $\mathrm{P}^{\mathrm{T}}, \mathrm{C}_{16: 1} \omega 5 c(42.5 \%)$, summed feature 3 (iso- $\mathrm{C}_{15: 0} 2-\mathrm{OH}$ and/or $\mathrm{C}_{16: 1} \omega 7 c ; 17.2 \%$ ), iso- $\mathrm{C}_{17: 0} 3-\mathrm{OH}$ $(16.1 \%)$ and iso- $\mathrm{C}_{15: 0}(8.5 \%)$, showed characteristic differences from the closest relatives (Table 2). Although similar fatty acid profiles were observed for strains of species belonging to the genus Flectobacillus, in which $\mathrm{C}_{16: 1} \omega 5 c$ is the major fatty acid, differences in the proportions of individual fatty acids were observed. The complete lack of summed feature 4 (one or more of $\mathrm{C}_{16: 1} \omega 7 c, \mathrm{C}_{16: 1} \omega 7 t$ and iso- $\left.\mathrm{C}_{16: 1} \omega 7 c 2-\mathrm{OH}\right)$, which is a major component in Arcicella strains, and the presence of summed feature 3 clearly indicated that strain $\mathrm{P}^{\mathrm{T}}$ is separate from the genus Arcicella. In the case of strain $\mathrm{P}^{\mathrm{T}}$, summed feature 3 was identified as iso- $\mathrm{C}_{15: 0} 2-\mathrm{OH}$.

The phylogenetic analysis showed that strain $\mathrm{P} 2^{\mathrm{T}}$ belonged to the family 'Flexibacteraceae' and it was clearly separated from other genera of this family (Fig. 1). The analysis of the almost-complete $16 \mathrm{~S}$ rRNA gene sequence (1351 bp) revealed that strain $\mathrm{P} 2^{\mathrm{T}}$ was a member of the phylum Bacteroidetes and had highest 16S rRNA gene sequence similarity with $F$. lacus CL-GP79 ${ }^{\mathrm{T}}(88.7 \%)$, which was isolated from a highly eutrophic pond. Other close relatives were $A$. rosea $\mathrm{TW}^{\mathrm{T}}(86.5 \%)$, A. aquatica NO-502 ${ }^{\mathrm{T}}(86.4 \%)$, F. roseus GFA- $11^{\mathrm{T}}(86.3 \%)$ and F. major DSM $103^{\mathrm{T}}(85.4 \%)$.
Table 2. Cellular fatty acid profiles of strain $P 2^{\top}$ and related taxa

Strains: 1, Siphonobacter aquaeclarae sp. nov. $\mathrm{P}^{\mathrm{T}} ; 2$, F. lacus CLGP79 $^{\mathrm{T}}$ (Hwang \& Cho, 2006); 3, F. major DSM $103^{\mathrm{T}}$ (Hwang \& Cho, 2006); 4, F. roseus GFA- $11^{\mathrm{T}}$ (Sheu et al., 2009); 5, A. aquatica NO$502^{\mathrm{T}}$ (Kämpfer et al., 2009) ; 6, A. rosea $\mathrm{TW}^{\mathrm{T}}$ (Kämpfer et al., 2009). Values are percentages of total fatty acids. ECL, Equivalent chainlength; tr, trace amount $(<1 \%)$; -, not detected.

\begin{tabular}{|c|c|c|c|c|c|c|}
\hline Fatty acid & 1 & 2 & 3 & 4 & 5 & 6 \\
\hline $\mathrm{C}_{14: 0}$ & $\operatorname{tr}$ & 1.7 & 1.0 & 5.7 & 1.4 & - \\
\hline $\mathrm{C}_{15: 0}$ & - & 4.3 & $\operatorname{tr}$ & $\operatorname{tr}$ & 2.0 & 4.5 \\
\hline$C_{16: 0}$ & 1.5 & 1.3 & 1.0 & 6.5 & 5.6 & 4.5 \\
\hline $\mathrm{C}_{15: 1} \omega 6 c$ & - & 4.2 & $\operatorname{tr}$ & $\operatorname{tr}$ & - & - \\
\hline $\mathrm{C}_{16: 1} \omega 5 c$ & 42.5 & 26.9 & 36.4 & 40.2 & 23.5 & 14.6 \\
\hline $\mathrm{C}_{17: 1} \omega 6 c$ & - & 1.5 & $\operatorname{tr}$ & - & - & - \\
\hline iso- $\mathrm{C}_{15: 0}$ & 8.5 & 12.1 & 9.5 & 15.0 & 8.5 & 16.7 \\
\hline anteiso- $\mathrm{C}_{15: 0}$ & $\operatorname{tr}$ & 2.4 & 2.5 & $\operatorname{tr}$ & 1.0 & - \\
\hline $\mathrm{C}_{15: 0} 3-\mathrm{OH}$ & - & 3.5 & - & - & - & - \\
\hline iso- $\mathrm{C}_{15: 0} 3-\mathrm{OH}$ & 4.1 & 3.8 & 3.7 & 6.9 & 5.6 & 6.3 \\
\hline $\mathrm{C}_{16: 0} 2-\mathrm{OH}$ & - & - & $\operatorname{tr}$ & 1.7 & - & - \\
\hline $\mathrm{C}_{16: 0} 3-\mathrm{OH}$ & 2.8 & 2.9 & 2.9 & 7.0 & 3.5 & 4.4 \\
\hline iso- $\mathrm{C}_{16: 0} 3-\mathrm{OH}$ & 1.5 & - & - & - & - & - \\
\hline iso- $\mathrm{C}_{17: 0} 3-\mathrm{OH}$ & 16.1 & 3.6 & 4.6 & 3.9 & 2.4 & 2.6 \\
\hline \multicolumn{7}{|l|}{ Summed features ${ }^{*}$} \\
\hline 2 & - & 1.4 & $\operatorname{tr}$ & 1.3 & - & - \\
\hline 3 & 17.2 & 19.2 & 10.8 & 8.9 & - & - \\
\hline 4 & - & - & - & - & 44.2 & 38.8 \\
\hline 5 & - & $\operatorname{tr}$ & 2.5 & - & - & - \\
\hline ECL 13.565 & 1.29 & $\operatorname{tr}$ & $\operatorname{tr}$ & - & - & - \\
\hline ECL 14.959 & 1.51 & 5.0 & 1.6 & - & - & - \\
\hline ECL 15.731 & - & - & 14.7 & - & - & - \\
\hline ECL 16.582 & 1.45 & $\operatorname{tr}$ & $\operatorname{tr}$ & - & - & - \\
\hline
\end{tabular}

${ }^{*}$ Summed features represent two or three fatty acids that cannot be separated by the Microbial Identification System (MIDI). Summed feature 2 consisted of $\mathrm{C}_{14: 0} 3-\mathrm{OH}$ and/or iso- $\mathrm{C}_{16: 1}$ I. Summed feature 3 consisted of iso- $\mathrm{C}_{15: 0} 2-\mathrm{OH}$ and/or $\mathrm{C}_{16: 1} \omega 7 \mathrm{c}$. Summed feature 4 consisted of one or more of $\mathrm{C}_{16: 1} \omega 7 c, \mathrm{C}_{16: 1} \omega 7 t$ and iso- $\mathrm{C}_{16: 1} \omega 7 c$ 2-OH. Summed feature 5 consisted of anteiso- $\mathrm{C}_{17: 1} \mathrm{~B}$ and/or iso$\mathrm{C}_{17: 1} \mathrm{I}$.

The DNA G + C content of strain $\mathrm{P}^{\mathrm{T}}$ was remarkably higher than its closest relatives $(54.5 \mathrm{~mol} \%)$ (Table 1$)$.

Therefore, on the basis of the low 16S rRNA gene sequence similarity between strain $\mathrm{P}^{\mathrm{T}}$ and recognized bacterial relatives and the results of the chemotaxonomic, biochemical and physiological analyses, strain $\mathrm{P} 2^{\mathrm{T}}$ is considered to represent a novel species in a new genus, for which the name Siphonobacter aquaeclarae gen. nov., sp. nov. is proposed.

\section{Description of Siphonobacter gen. nov.}

Siphonobacter (Si.pho.no.bac'ter. Gr. n. siphô -ônos tube, pipe; N.L. masc. n. bacter rod; N.L. masc. n. Siphonobacter rod-shaped bacterium from a pipeline, referring to the source of isolation of the type strain of the type species). 


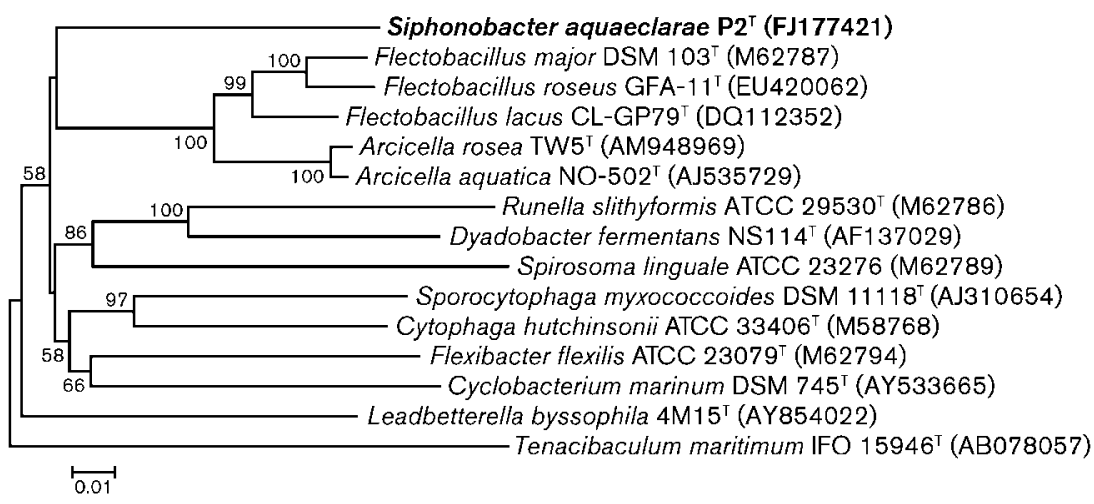

Fig. 1. Neighbour-joining phylogenetic tree based on 16S rRNA gene sequences showing the position of strain $\mathrm{P} 2^{\top}$ among various representative members of the family 'Flexibacteraceae'. Bootstrap values ( $>50 \%$ ) based on 1000 replications are shown at branch nodes. Bar, 0.01 substitutions per site.
Gram-negative, facultatively anaerobic, non-motile rods occurring singly or in pairs. Positive for catalase and negative for oxidase and nitrate reduction. Major whole-cell fatty acids are $\mathrm{C}_{16: 1} \omega 5 c$, iso- $\mathrm{C}_{15: 0} 2-\mathrm{OH}$, iso- $\mathrm{C}_{17: 0} 3-\mathrm{OH}$ and iso- $\mathrm{C}_{15: 0}$. The major isoprenoid quinone is menaquinone MK-7. The main polar lipid is phosphatidylethanolamine. On the basis of $16 \mathrm{~S}$ rRNA gene sequence analysis, the genus is affiliated to the family 'Flexibacteraceae' in the phylum Bacteroidetes. The type species is Siphonobacter aquaeclarae.

\section{Description of Siphonobacter aquaeclarae sp. nov.}

Siphonobacter aquaeclarae (a.qua.e.cla' ra.e. L. n. aqua -ae water; L. adj. clarus $-a-u m$ clear, bright; N.L. gen. n. aquaeclarae of/from a clear water).

In addition to properties described for the genus, the species has the following characteristics. Grows well on R2A agar, nutrient and TSA, but not on MacConkey agar. Cells are $1.3-2.7 \mu \mathrm{m}$ long and $0.3-0.4 \mu \mathrm{m}$ wide. No gliding motility observed. Grows at $4-37{ }^{\circ} \mathrm{C}$ and $\mathrm{pH} 5-9$, but not with $2.5 \%$ $\mathrm{NaCl}$. Methyl red test is positive but Voges-Proskauer test is negative. Hydrolyses gelatin, starch and Tween 80 , but not casein or urea. For sole carbon sources, produces acid from cellobiose, D-fructose, L-fucose, D-galactose, gentiobiose, Dglucose, lactose, maltose, D-mannose, melezitose, melibiose, raffinose, L-rhamnose, starch, sucrose, D-tagatose, trehalose, turanose, $\mathrm{N}$-acetylglucosamine, amygdalin, arbutin and inulin, but not from D-fucose, D-ribose, L-sorbose, Dadonitol, D-arabitol, dulcitol, erythritol, glycerol, inositol, D-mannitol, D-sorbitol, xylitol or gluconate. Positive for alkaline phosphatase, esterase (C4), esterase lipase (C8), leucine arylamidase, valine arylamidase, cystine arylamidase, trypsin, $\alpha$-chymotrypsin, acid phosphatase, naphthol-ASBI-phosphohydrolase, $\alpha$-galactosidase, $\beta$-glucuronidase, $N$ acetyl- $\beta$-glucosaminidase and $\alpha$-fucosidase. The genomic DNA $\mathrm{G}+\mathrm{C}$ content of the type strain is $54.5 \mathrm{~mol} \%$.

The type strain, $\mathrm{P}^{\mathrm{T}}\left(=\mathrm{DSM} 21668^{\mathrm{T}}=\right.$ NCAIM B $\left.02328^{\mathrm{T}}\right)$, was isolated from biofilm developed on the inner surface of an ultrapure cooling water pipeline system in a Hungarian power plant.

\section{Acknowledgements}

This research work was supported by the Cooperative Research Center for Environmental Sciences, Eötvös Loránd University, ELTECRCES, Pázmány P. stny 1/A, Budapest, H-1117 Hungary.

\section{References}

Altschul, S. F., Madden, T. L., Schäffer, A. A., Zhang, J., Zhang, Z., Miller, W. \& Lipman, D. J. (1997). Gapped BLAST and PSI-BLAST: a new generation of protein database search programs. Nucleic Acids Res 25, 3389-3402.

Branda, S. S., Vik, A., Friedman, L. \& Kolter, R. (2005). Biofilms: the matrix revisited. Trends Microbiol 13, 20-26.

Cashion, P., Holder-Franklin, M. A., McCully, J. \& Franklin, M. (1977). A rapid method for the base ratio determination of bacterial DNA. Anal Biochem 81, 461-466.

Claus, M. (1992). A standardised Gram staining procedure. World J Microbiol Biotechnol 8, 451-452.

Collins, M. D., Pirouz, T., Goodfellow, M. \& Minnikin, D. E. (1977). Distribution of menaquinones in actinomycetes and corynebacteria. J Gen Microbiol 100, 221-230.

Cottrell, M. T. \& Kirchman, D. L. (2000). Natural assemblages of marine proteobacteria and members of the Cytophaga-Flavobacter cluster consuming low- and high-molecular-weight dissolved organic matter. Appl Environ Microbiol 66, 1692-1697.

Cowan, S. T. \& Steel, K. J. (1974). Manual for the Identification of Medical Bacteria, 2nd edn. London: Cambridge University Press.

Furuhata, K., Kato, Y., Goto, K., Saitou, K., Sugiyama, J., Hara, M. \& Fukuyama, M. (2008). Identification of pink-pigmented bacteria isolated from environmental water samples and their biofilm formation abilities. Biocontrol Sci 13, 33-39.

Gromov, B. V. (1963). A new bacterium of the genus Microcyclus. Dokl Akad Nauk SSSR 152, 733-734 (in Russian).

Groth, I., Schumann, P., Weiss, N., Martin, K. \& Rainey, F. A. (1996). Agrococcus jenensis gen. nov., sp. nov., a new genus of actinomycetes with diaminobutyric acid in the cell wall. Int J Syst Bacteriol 46, 234239.

Groth, I., Schumann, P., Rainey, F. A., Martin, K., Schuetze, B. \& Augsten, K. (1997). Demetria terragena gen. nov., sp. nov., a new genus of actinomycetes isolated from compost soil. Int J Syst Bacteriol 47, 1129-1133.

Hugh, R. \& Leifson, E. (1953). The taxonomic significance of fermentative versus oxidative metabolism of carbohydrates by various gram negative bacteria. J Bacteriol 66, 24-26. 
Hwang, C. Y. \& Cho, B. C. (2006). Flectobacillus lacus sp. nov., isolated from a highly eutrophic pond in Korea. Int J Syst Evol Microbiol 56, 1197-1201.

Kämpfer, P., Lodders, N. \& Busse, H.-J. (2009). Arcicella rosea sp. nov., isolated from tap water. Int J Syst Evol Microbiol 59, 341-344.

Kirchman, D. L. (2002). The ecology of Cytophaga-Flavobacteria in aquatic environments. FEMS Microbiol Ecol 39, 91-100.

Lane, D. J. (1991). 16S/23S rRNA sequencing. In Nucleic Acid Techniques in Bacterial Systematics, pp. 115-175. Edited by E. Stackebrandt \& M. Goodfellow. Chichester: Wiley.

Mesbah, M., Premachandran, U. \& Whitman, W. B. (1989). Precise measurement of the $\mathrm{G}+\mathrm{C}$ content of deoxyribonucleic acid by highperformance liquid chromatography. Int J Syst Bacteriol 39, 159-167.

Minnikin, D. E., Collins, M. D. \& Goodfellow, M. (1979). Fatty acid and polar lipid composition in the classification of Cellulomonas, Oerskovia and related taxa. J Appl Bacteriol 47, 87-95.

Nikitin, D. I., Strompl, C., Oranskaya, M. S. \& Abraham, W. R. (2004). Phylogeny of the ring-forming bacterium Arcicella aquatica gen. nov., sp. nov. (ex Nikitin et al. 1994), from a freshwater neuston biofilm. Int J Syst Evol Microbiol 54, 681-684.

Rickard, A. H., Stead, A. T., O’May, G. A., Lindsay, S., Banner, M., Handley, P. S. \& Gilbert, P. (2005). Adhaeribacter aquaticus gen. nov., sp. nov., a Gram-negative isolate from a potable water biofilm. Int $J$ Syst Evol Microbiol 55, 821-829.

Saitou, N. \& Nei, M. (1987). The neighbor-joining method: a new method for reconstructing phylogenetic trees. Mol Biol Evol 4, 406425.
Sheu, S.-Y., Chiu, T. F., Cho, N.-T., Chou, J.-H., Sheu, D.-S., Arun, A. B., Young, C.-C., Chen, C. A., Wang, J.-T. \& Chen, W.-M. (2009). Flectobacillus roseus sp. nov., isolated from freshwater in Taiwan. Int J Syst Evol Microbiol 59, 2546-2551.

Smibert, R. M. \& Krieg, N. R. (1994). Phenotypic characterization. In Methods for General and Molecular Bacteriology, pp. 607-654. Edited by P. Gerhardt, R. G. E. Murray, W. A. Wood \& N. R. Krieg. Washington, DC: American Society for Microbiology.

Stead, D. E., Sellwood, J. E., Wilson, J. \& Viney, I. (1992). Evaluation of a commercial microbial identification system based on fatty acid profiles for rapid, accurate identification of plant pathogenic bacteria. J Appl Bacteriol 72, 315-321.

Tamaoka, J. \& Komagata, K. (1984). Determination of DNA base composition by reversed-phase high-performance liquid chromatography. FEMS Microbiol Lett 25, 125-128.

Tamura, K., Dudley, J., Nei, M. \& Kumar, S. (2007). MEGA4: molecular evolutionary genetics analysis (MEGA) software version 4.0. Mol Biol Evol 24, 1596-1599.

Tarrand, J. J. \& Gröschel, D. H. (1982). Rapid, modified oxidase test for oxidase-variable bacterial isolates. J Clin Microbiol 16, 772-774.

Yamada, K. \& Komagata, K. (1972). Taxonomic studies on coryneform bacteria. IV. Morphological, cultural, biochemical, and physiological characteristics. J Gen Appl Microbiol 18, 399-416.

Zwart, G., Crump, B. C., Kamst-Van Agterveld, M. P., Hagen, F. \& Han, S.-K. (2002). Typical freshwater bacteria: an analysis of available $16 \mathrm{~S}$ rRNA gene sequences from plankton of lakes and rivers. Aquat Microb Ecol 28, 141-155. 